\title{
Dissemination of Waves in Thin Plates
}

František Klimenda, Lenka Rychlíková, Štefan Husár, Josef Soukup

Faculty of Mechanical Engineering, J. E. Purkyne University in Usti nad Labem. Pasteurova 3334/7, 40001 Usti nad Labem. Czech Republic. E-mail: frantisek.klimenda@ujep.cz

The article deals with the wave propagation in thin plate. A wave was caused by the impact force. In the first part of an article the Kirchhoff's theory of thin isotropic plate is given. It is a vertical displacement $w$, angles of rotation tangent $\varphi_{x}$ and $\varphi_{y}$, bending stresses $\sigma_{x}, \sigma_{y}$, shear strength $\tau_{y x}=\tau_{y x}$, shear strength from displacement forces $\tau_{\mathrm{xz}}, \tau_{\mathrm{yz}}$. In the second part of an article is solved a Kirchhoff's theory by analytically in MATLAB programme. Analytically were solved only displacements $u, v$ and velocity $\dot{u}, \dot{v}$. The solution is performed for two plate materials - aluminium and steel. By result are deformations and velocities graphs in the $\boldsymbol{x}$-axis and the $\boldsymbol{y}$-axis at the measurements points given. In the conclusion of an article is comparing of individual deformations and velocities graphs.

Keywords: Displacement, Velocity, Vibration, Thin Plate

\section{Acknowledgement}

The research work is supported by the SGS-UJEP, Czech Republic.

\section{References}

[1] BREPTA, R., OKROUHLÍK, M., VALEŠ, F. (1985). Vlnové a rázové děje v pevných tělesech a metody jejich řě̌ení. 1. vydání. Praha: Academia, $172 \mathrm{~s}$.

[2] VOLEK, J. (1990). Ráz a přenos impulsu v soustavě elastických a viskoelastických jedno a dvourozměrných těles, Závěrečná výzkumná práce pro ÚT ČSAV, Litoměřice

[3] KLIMENDA, F., SOUKUP, J. (2015). Deformace hliníkové desky, In. Sborník příspěvků na CD ROM z 9. Mezinárodní konference Aluminium 2015, 20. - 23. 10. 2015 v Bystřici nad Pernštejnem, FVTM UJEP v Ústí n. L., ISBN 978-80-7414-379-3

[4] SOUKUP, J., VOLEK, J. (2007). A thin rectangular viscoelastic orthotropic plate under transverse impuls loading, $9^{\text {th }}$ Conference on Dynamical Systems Theory and Applications, Poland

[5] KLIMENDA, F., SOUKUP, J., ŽMINDÁK, M. (2016). Deformation of Aluminium Thin Plate, Manufacturing Technology, Vol. 16, No 1, pp 124-129, ISSN 1213-2489

[6] ZMINDAK, M., PELAGIC, Z., SOUKUP, J. (2015). Analysis of Fiber Orientation Influence to Dynamic Properties of Composite Structures, Manufacturing technology, Vol. 15, No. 3, pp 490-494, ISSN 1213-2489 